\title{
The Response of Tanzania Higher Learning Institutions to e- Learning during Covid-19 Pandemic
}

\author{
Wilson Pholld Mwakyusa \\ Orcid: https://orcid.org/0000-0003-4957-0672 \\ General Management Department, Tanzania Institute of Accountancy, Tanzania \\ Lucas Masome Ng`webeya \\ Orcid: https://orcid.org/0000-0002-0897-4948 \\ General Management Department, Tanzania Institute of Accountancy, Tanzania
}

Corresponding Mail: wilson.mwakyusa@tia.ac.tz

\begin{abstract}
Copyright resides with the author(s) in terms of the Creative Commons Attribution CC BY-NC 4.0. The users may copy, distribute, transmit and adapt the work, but must recognize the author(s) and the East African Journal of Education and Social Sciences
\end{abstract}

\begin{abstract}
This study examined how the Tanzanian Higher Learning Institutions (HLIs) responded to the e-learning implementation during the COVID-19 pandemic period. It employed the Actor Network Theory that informs the socio-technical interactions. The study employed an explorative case study design with qualitative techniques, involving a total of 13 participants from selected HLIs. A thematic analysis framework was used to analyze data. The study revealed that HLIs in Tanzania have partially implemented e-learning systems and there is limited use of e-learning technology among HLIs in Tanzania. The e-learning implementation is in terms of tuition fee payment, examination results, online learning and presentation of research proposals through mobile technologies and Zoom. It is important for the government to make more emphasis on development of e-learning policies which will increase participation, commitment and accountability in HLIs. It is also important for HLIs to redefine e-learning strategies and develop facilities that will enhance transformations in teaching and learning amidst the Covid 19 Pandemic. This requires good internet networks as well as availability of robust learning management systems. Furthermore, HLIs should establish collaboration with other learning institutions within and outside the country for sustainable e-learning outcomes. .
\end{abstract}

Keywords: E-learning; HLIs; COVID-19; ICT, Actor Network Theory

How to cite: Mwakyusa, W. P. and Ng'webeya, L. M. (2022). The Response of Tanzania Higher Learning Institutions to e- Learning during Covid-19 Pandemic. East African Journal of Education and Social Sciences 3(1), 19-28. Doi: https://doi.org/10.46606/eajess2022v03i01.0142.

\section{Introduction}

The emergence of Information and Communication Technology (ICT) has provided learners with tremendous opportunities for educational access. This brings the practice of using electronic resources as a formal learning system, specifically in higher learning institutions. As a result, the use of internet connectivity and computer systems for learning whether remotely or within classrooms reflects the practice of e-learning systems (Aboagye, Yawson, \& Appiah, 2020). Lwoga (2012) described e-learning as the design, development and delivery of instructional materials through technologies for the purpose of enhancing and supporting the teaching and learning process.

The teaching and learning system is among the industries affected by the global spread of COVID-19 virus. Recently, governments around the world advised higher learning institutions (HLIs) to compliment traditional learning systems with elearning systems as a means of combating the COVID-19 pandemic (Mahyoob, 2020; Maatuk, et

19 East African Journal of Education and Social Sciences (EAJESS) 3(1)19-28 
al., 2021).This is based on the fact that online learning mode supports HLIs over the world in maintaining social distancing to prevent or reduce the spread of COVID 19 virus (Mahyoob, 2020). Elearning not only benefits learners and instructors but it is also the most effective way to reduce the spread of COVID 19 Virus (Lizcano, et al., 2020).

Governments in the developing countries such as Tanzania through ministries of education have set out ICT strategies to ensure the equitable access to ICT resources for teachers, students and administrators (Ministry of Education, 2016; Twaakyondo \& Munaku, 2012). However, in developing countries, majority of higher learning institutions do not use e-learning systems as a complete method of learning (Kwofie, et al., 2020). Only a few HLIs in the developing world have changed their teaching and learning process into electronic mode of learning. As a result, majority of $\mathrm{HLIs}$ in these countries, including Tanzania, continued to teach in the traditional way during the COVID 19 pandemic outbreak.

Previous studies investigated on the impact, challenges and opportunities from Covid-19 spread to e-learning implementations from the perspectives of instructors and students (Aboagye et al., 2020; Kwofie et al., 2020). The studies showed that e-learning systems have limited applicability in HILs (Maatuk, et al., 2021). Inadequate applicability of e-learning systems in the developing world can be attributed to poor attitude among users (Ramadan, Elatresh, Alzain, \& Tokeser, 2019; Kwofie et al., 2020), low skills and knowledge and insufficient ICT infrastructure (Innocent \& Masue, 2020; Kwofie et al., 2020; Mwakyusa \& Mwalyagile, 2016).

Consequently, HLIs which have attempted to fully implement e-learning systems such as the use of the moodle learning system have experienced unsatisfactory outcomes (Kwofie, 2015). Prior studies on e-learning implementation have focused on analyzing e-learning from the individual perspectives (students and lecturers) and have been less detailed from the institutional perspective in HLIs (Kwofie et al., 2020). Similarly, research on analysis on institutional implementation of elearning systems is inadequate to develop frameworks that serve as insightful guidance for institutions. This study therefore sought to shade light on responses of higher learning institutions in Tanzania to e-learning implementation during the
Covid-19 Pandemic period. The study was guided by the following research questions:

1. To what extent is e-learning practiced in Tanzanian Higher Learning Institutions during the Covid-19 pandemic?

2. How did HLIs actors influence the implementation of e-learning among HLIs during the COVID 19 pandemic in Tanzania?

\section{Theoretical Underpinnings}

The study was underpinned by the Actor Network Theory (ANT) which emphasizes on the construction of social structures by both human and non-human entities (Latour, 2005). In the ANT concept, the social structures are constructed through the network of aligned interests such as organizations, people and standards known as actors-network (Latour, 2005; Law, 1992; Walsham, 1997).The actors- network is defined by four translational moments such as problematiazation, interessement, enrolments and mobilizations (Latuor, 2005).This study looked at translation moments in ANT as the lens for understanding and improving the relationship between people and e-learning systems.

A problematization moment is the initial stage in which actors define problems and establish an obligatory passage point (Callon, 1986). In this stage, the principal actors who are the central actors, impose new ideas and define the nature of the problem, then influence other actors to accept a way forward through defined OPP (Law, 1986). In this way, the obligatory passage point becomes the way for actors to align their interest so that they have strong shared focus. This stage was useful because it describes the current state of challenges and the need for the diffusion of e-learning implementation in HLIs, particularly during COVID19 Pandemic.

The second stage is interessement moments of translation, which involve negotiations with other actors in order to convince/persuade them to align with the focal actors (Sarker \& Sidorova, 2006). The basic approach is that actions proposed in the problematization process are carried out with different devices being used by different actors (Kwofie et al., 2020). In this stage, the main actor attempts to lock other actors into positions in networks of the actors that have been offered to them (Afarikumah \& Kwankam, 2013). The interessement moment of translation helps 
researchers in understanding the reasons driving the interest of actors. For instance, the e-learning initiative has been long supported by governments but the process of making decisions among actors may slow the pace of e-learning diffusion among HLIs (Kwofie et al., 2020), particularly those owned by the government.

The enrollment is the third moment of translation in which main actors and other actors inter-relate with various roles to allow other actors to be enrolled in the network (Callon, 1986). The enrollment moment entails mutual negotiations (such as bargaining and making concessions), as well as strength trials aimed at mobilizing the actor's network. According to Sarker and Sidorova (2006) and Shin (2010), the enrollment moment creates the willingness of actors to accept and follow the requirements of the actors-network seamlessly. The study used this knowledge to investigate the strength of the actor network that has been constructed as well as the extent to which HLIs in the government and other educational sectors in Tanzania could remain and strengthen the actor-network.

Mobilization is the fourth moment of translation that seeks to maintain a commitment to a cause of actions and the obligatory passage point (Afarikumah \& Kwankam, 2013). At this point, the main actor ensures that all actors in the network are adequately representing the masses (Callon, 1986). This study employed the concept of mobilization to understand alliances among actors such as government, institutions, learners and lecturers as well as providing support for the implementation of e-learning systems as strategy to combat COVID-19 spread in developing countries like Tanzania.

This study employed the ANT as the theoretical foundation to establish the complex socio technical processes associated with the e-learning system development, implementation and assessment (Islam, Mäntymäki \&T urunen, 2019) and to describe the e-learning trajectory as addressed by Markus and Rowe (2018) who state that "change occurs through the importation of heterogeneous new elements (e.g., ideas, actors and resources) into an entity (or loss of elements preexisting in the entity) and by the creation of new linkages among the entity's elements" (p.1267). ANT provides a link between the emerging learning process through computer mediated network that comprises of heterogeneous collective actors (such as learners and instructors) and technologies which define objectives (Latour, 2005; Law, 1992). This study further adopted the ANT conceptualization as described by Walsham (1997) who successfully applied the theory in investigating its implications in information systems development research. More specifically, ANT provides the framework for understanding of the social interactions between technology and human processes through the analysis of socio-technical perspectives (Baines, 2017; Bijker, Hughes, Pinch, \& Douglas, 2012; Islam, et al., 2019; Shim \& Shin, 2019).

Table 1: Summary of ANT Constructs

\begin{tabular}{ll}
\hline $\begin{array}{l}\text { Actor or Actant } \\
\text { Actor Network }\end{array}$ & $\begin{array}{l}\text { Both human beings and nonhuman actors such as technological artifacts } \\
\text { Heterogeneous network of aligned interest, including people, organizations, and } \\
\text { standards }\end{array}$ \\
$\begin{array}{l}\text { Translation and } \\
\text { Creating body of allies, human and nonhuman, through a process of translating their }\end{array}$ \\
$\begin{array}{l}\text { Delegates and } \\
\text { interests to be aligned with the actor-network }\end{array}$ & $\begin{array}{l}\text { Delegates are actors who "stand in and speak for" particular viewpoints which have } \\
\text { been inscribed in them, e.g., software as frozen organizational discourse }\end{array}$ \\
Irreversibility & $\begin{array}{l}\text { The degree to which it is subsequently impossible to go back to point where alternative } \\
\text { possibilities exists }\end{array}$ \\
Black box & A frozen network element, often with properties of irreversibility \\
Immutable & Network element with strong properties of irreversibility, and effects which transcend \\
mobile & time and place, e.g., software standards
\end{tabular}

ANT as the theoretical lens guided the study in understanding the constructions of actors-network during the e-learning implementation among HLIs. The translation moments of ANT gives light on how the processes, negotiations and controversies lead into e-learning implementation among HLIs in Tanzania. This is because ANT draws attention to an institutional nature of implementation of new systems such as e-leaning systems to leverage the HLIs performance, accountability, quality of learning process in terms of resources and online knowledge delivery. The implementation of e-learning systems is enhanced by the existence of actor network interactions within an institutional structure and 
hence creates commitment during the implementation process (Kwofie et al., 2020). It is from this background that the study sought to

\section{Methodology}

\section{Research design}

This study employed a case study design in which the qualitative approach was used in generating data from e-learning stakeholders among HLIs in Tanzania. The study was guided by the interpretivism philosophical paradigm which is based on the assumption that reality and knowledge are subjectively constructed and can better explain the complex socio-technical interaction (Walsham, 1995). This implies that reality and knowledge are made meaningful through actors' understanding of events (Elbardan \& Kholeif, 2017; Putnam \& Banghart, 2017). In the same line of understanding, this study used the interpretive method to inform the data collection and analysis. This assumption is based on the interpretive approach's belief that social reality is subjectively shaped by human experiences and contexts (Elbardan \& Kholeif, 2017).

\section{Population and Sampling}

The study purposefully selected participants from institutional management teams as the source of information in order to gain micro understanding of the institutions. Data was collected from thirteen participants in two phases from February to May 2021. In the first phase, three participants from the management team (two academic coordinators and one official in the directorate of academic, research and consultancy) were purposefully selected for the purpose of giving detailed understanding of elearning implementation progress and strategies made by the institutions. In the second phase, data was collected from ten participants who are the users and supporters of learning management systems in HLIs. During the data collection process, the experience in using ICT tools for teaching and learning purposes were considered. For instance, the experience and basic knowledge of using web 2.0 services, moodle learning management systems and usage of academic records information systems for managing students' academic records in HLIs. Data was collected from potential participants (i.e. the students, librarian, lecturers, and HoDs within HLIs) so as to address specific issues and opinions or perceptions towards e-learning implementations among HLIs as a way of combating COVID 19 virus spread. The potential participants were from establish the responses of Higher Learning Institutions to e-learning implementation strategies during the Covid-19 pandemic in Tanzania.

Tanzania Institute of Accountancy (TIA), Dar-esSalaam University College of Education (DUCE) and Open University of Tanzania (OUT). The selected HLIs were purposefully selected and were situated nearby and among the HLIs which are practicing partial or blended learning (Mtebe \& Raphael, 2018).

\section{Data Collection and Analysis}

The interview and documentary review were employed as data collection techniques. The semi structured interview guide was used as a tool for guiding the interview process. The interview guideline was prepared based on the literature and themes identified from ANT. The ANT served to direct the interview process towards the area of interest. Sixteen interviews were conducted at an average of 40 to 60 minutes per interview conversion. The interview response was recorded in a summary notebook and was audio recorded upon the participant consent. The interview was conducted until saturation where researchers found no new idea emerging about the e-learning implementation. The interview response was supported by the analysis of two policy documents pertaining to e-learning system implementation. The collected data were thematically analyzed as informed by the ANT theory.

\section{Validity and Reliability}

The validity and reliability of the interview guide (semi-structured interview guide) were ensured by conducting a pilot test by involving two lecturers and 2 third year undergraduate students. Two important stages were conducted that is preinterview and post interview after data collection and analysis. As a result of the pilot analysis, slight modifications were made to ensure the semistructured questions focused on the subject under investigations and context. However, one more question emerged during the interview process that clarifies the e-learning implementation strategies and practices among HLIs in Tanzania. This gives light that the instruments were reliable and valid for this research work.

\section{Ethical considerations}

The researchers sought permission and informed consent from participants before the 
commencement of the data collection process. The participants were allowed to enthusiastically participate and audio record was done upon their consent. Also the participants were ensured with confidentiality, anonymity and protection that no any identities or personal details would be revealed during and after the research process.

\section{Findings and Discussions}

Presentation of findings and discussions of the results were guided by two research questions as follows

Research question 1: To what extent is e-learning practiced in Tanzanian Higher Learning Institutions during the Covid-19 pandemic?

It was revealed that e-learning was partially practiced. Areas that practiced e-learning include library, examination results section, registration and payment of tuition fee. Particularly, participants revealed that: "Now days we don't suffer from staying in queue for fee payment as we pay online through mobile money (MPESA, TIGOPESA and Simbanking) and make online registration through personal accounts" (Student 2). It was further revealed that:

To some extent there are some of the electronic areas that we practice such as access to online library, student registration system and examination results such that everyone can access in his or her own registered account. Another service for e-learning is online payment, with payment status reflected immediately in our accounts, and finally, access to the online time table" (Student 1).

Also a lecturer revealed that:

"It is now easy for me. Once I complete marking tests and assignment, I just upload to the systems without direct or face-to-face interaction with my student" (Lecturer 1).

Furthermore, the study went further to establish on the extent to which online teaching was conducted in HLIs. A participant revealed that:

"....It is just difficult to make traditional teaching in our environment because first of all the class is too big to accommodate all students at the same time. To me I like to send assignments to students who then submit through email and I respond to them" (Lecturer 3).
The statement was supported by one of the participants that "some of our lecturers send resources and materials in the form of web links through WhatsApp groups and at the same time we students do submit assignments via email on a specified date" (Student 1). According to study findings of Innocent and Masue (2020), blended learning approaches have been hindered by poor attitude, insufficient ICT infrastructures and weak skills in conducting e-learning system among users. Therefore, there is a need to educate stakeholders on the importance of online platforms of teaching and learning and to ensure adequate supply of online learning items.

Research question 2: How did HLIs actors influence the implementation of e-learning among HLIs during the COVID 19 pandemic in Tanzania?

The analysis for this question was informed by the ANT theoretical framework that explains the sociotechnical interactions during the e-learning process through the translation process. In the translation process, the leader or designer identifies and proposes solutions such as e-learning strategy for HLIs to be employed for the teaching and learning process and is inscribed into the e-learning systems (artifacts). This means e-learning systems becomes an actor and compels its inscription to other actors such as HLIs policy and decision makers to achieve the objective. In this way, technical actors participate in constructing heterogeneous actor's networks that mobilize actants (e-learning strategy, ministry of education, HLIs, Management teams, Lecturers, and students) towards e-learning through a series of negotiations. Thus in order to describe the dynamic negotiation process between HLIs actors and how they influence e-learning implementation strategy, the study used the moments of translation namely problematization, interessment, enrolment and mobilization to explain the e-learning implementation process among HLIs in Tanzanian context. This is because the implementation of e-learning systems in HLIs is considered as a pragmatic translation process through which actors are enrolled in the e-learning implementation network.

\section{Problematization}

This is the moments where the key actors such as governments and HLIs top managements make themselves as central key through identifying nature of problems and influence other actors to accept the proposed solutions as method of solving the 
defined problem. For instance, findings reveal that, the Ministry of Education, Science and Technology is the main actor for effective e-learning implementation. The government through the ministry should produce policies and strategies towards e-learning. It also has to set strategies to ensure that internet is available in all HLIs for effective learning to take place. Documentary analysis indicated that the ministry of education, science and technology has developed a policy to guide the integration of ICT in Basic Education. It is guided by the overall objectives of education policies, and relevant national development policies, including the Tanzania National ICT Policy of 2003. Supporting this strategy, other development partners such as African Development Bank Group (AfDB) and the United States Agency for International Development (USAID) put more effort to ensure e-learning is successfully implemented in Sub-Saharan African Countries (Mtebe 2015). For instance, AfDB through African Virtual University (AVU) supports countries and higher learning institutions to cope with the effects of COVID-19 pandemic in Sub-Saharan African Countries. In Tanzania, the AVU center at the University of Dar es Salaam was supported with free e-resources whose link consists of more than 1600 resources including videos and learning modules for mathematics, physics, teacher education and computer sciences. In supporting the objective, the AVU released the guide for policy formulation.

The Center for Virtual Learning at the University of Dar-es-salaam was established since 1998 for the purpose of coordinating e-learning services (Mtebe, Fulgence, \& Gallagher, 2021). However, the challenges emerged here is that local universities or HLIs faced the challenge of expensive bandwidth connectivity and weak ICT infrastructures. In addition, the selection and management of effective ICT infrastructure and appropriate policies that would support the success of technology enabled learning expectations from HLIs becomes a challenge. Thus, this creates the importance that focal actors such as government, HLIs management need to device a means to influence attitudes of HLIs managements towards e-learning. This means that the HLIs authorities prioritize and approve the e-learning policies and strategies as the main OPP of e-learning projects for HLIs.

\section{Interressment}

The interressment is the stage in which main actor such as HLIs management teams arouse other actors like lecturers and students through interposing and defining linkages using OPP. The findings show that during the COVID 19 outbreak, lecturers tried to stay and work from home through the use of their hand held devices using mobile internet bundles to enable the learning process between postgraduate students and lecturers. For instance one of the participants exerted that: "In response to the strategies of e-learning implementation in our institution, we normally encourage student to use their handheld gadgets such as tablets and smart phones to access elearning platform" (Academic1).

According to Mtebe et al., (2021) the management team at the University of Dar es Salaam made a decision to negotiate with some mobile firms to bridge the internet connectivity challenges during the COVID 19 outbreak. For instance, the university made a contract with Vodacom Tanzania that some essential websites for teaching and learning were registered through special IP addresses which were accessed at a very low cost when using the Vodacom network channel.

The government of Tanzania has shown effort towards e-learning process by allowing live Television sessions (i.e. Tanzania Broadcasting Corporations) and Radio stations to conduct various education programs to support access to online secondary education direct from home which arouse interest for HLIs to become necessary actors towards e-learning system during COVID-19 outbreak.

In aligning Interest for e-learning implementation, it was pointed out that

".....we normally create WhatsApp group either for group discussion or for class information. In these groups we share some information about the class issues or share materials like tests questions and sometimes we discuss certain topics provided" (Student 2). "Sometimes lecturers provide some clarifications on how to go about with given assignments provided or more details about the topic questions through these platforms [WhatsApp group]" (Student 5). In addition, an academic coordinator further explains that:

....during COVID-19 pandemic
outbreak, we tried to do some
presentations online using ZOOM
technology (e.g. research proposals
defense). This gave us green light that
it is essential to enhance our e-


learning platforms to avoid unnecessary delays for students to complete their studies on time (Academic 1).

The statement shows that HLIs utilized the elearning opportunities in the learning process. Despite the fact that students were at home, they had access to teaching and learning materials which simplified their learning process. This signifies that the government of Tanzania as focal actor provided support to e-learning activities in universities. But it seems that the technical experts to support elearning in the normal environment of users such as learners and lecturers in HLIs is a problem that makes delay in the e-learning implementation. Also it was observed that unnecessary delays of elearning implementation were due to low awareness of the learning system, lack of basic skills in using IT facilities and lack of skills for integrating ICT in teaching and learning. Nhatuve (2021) add that these factors impacted the effectiveness of elearning implementation during the COVID-19 outbreak in developing countries.

\section{Enrolment}

Enrolment stage requires actions for interested actors to implement and participate in the solution. For instance, the finding shows the existence of negotiations between the potential allies. This was evidenced at the Tanzania Institute of Accountancy management who together struggled to sustain the online learning process. For instance, the management team that was held on May 2020 considered engaging on online learning management systems as among the solutions to reduce the COVID 19 spread within the institute. They decided that the institute must acquire a stable storage space (hardware) to allow huge amount of materials and assignments to be uploaded and stored as much as possible. Moreover the strategies for strengthening and implementing learning management system such as moodle were the main agenda. The directive from the government through the Prime Minister's Office and the Ministry of Education and Technology caused the management of the institute and other universities in Tanzania to be enrolled as they are required to define modalities to implement and strengthen e-learning platform. The enrolment moment of translation insists on aligning the elearning initiatives with the institutional strategies and policies.
However, this study found evidence that there is lack of sustainable linkage between e-learning initiatives and institutional strategies. For instance a participant report that: "...... I think we need more clear guide and strategies to support the completion or implementation of e-learning in the institute" (Lecturer 4).

Another action to e-learning implementation strategy is through engaging in online resources subscriptions. The evidence was provided by a librarian who stressed that ".......we have already subscribed to different databases for student access resources like emerald insight, Ebsco host, and Research 4 life in which they can access them". The librarian further advised students to be registered so that they can acquire ability of accessing eresource in their respective areas.

Findings reveal that despite the fact that HLIs have shown struggle towards e-learning, still the HLIs have no proper institutional direction towards elearning implementation including defined vision for e-learning, budgets and priorities (Ghasia, Machumu, Zhu \&DePryck, 2020).

However some HLIs in Tanzania have tried to establish and get enrolled into blended learning (Mtebe, 2015). Some of the HLIs are Mzumbe university (Innocent \& Masue, 2020), University of Dar es salaam, Open University of Tanzania (Mtebe et al., 2021; Mtebe \& Raphael, 2018) and Sokoine University of Agriculture (SUA) (Mtega, 2021).This is in line with Ghasia, Machumu, Zhu and DePryck (2020) who argue that the process of implementing e-learning management systems comprises of adequate strategic preparation, collaboration, trust establishment and organizational knowledge.

\section{Mobilization}

Findings reveal that the Ministry of Education, Science and Technology and the government at large are the main actors in mobilizing e-learning implementations in HLIs although it catches up slowly and may take time for all HLIs in Tanzania to converge into complete e-learning. HLIs are gradually enrolling into stable actor networks. For instance, Mzumbe University is on progress to establish online courses to be conducted either in blended or complete e-learning upon completion of preparation (Ghasia et al., 2020). Since the introduction of e-learning in Mzumbe University, the university successfully managed to establish collaborations with other universities outside the country. The current status shows some of the 
programs like Master of Science in Health Monitoring and Evaluations are still in partial online mode.

Therefore, e-learning implementation among HLIs in Tanzania is the best way of facilitating the teaching and learning process during the COVID-19 pandemic even though there is limited expertise in e-learning skills and commitment among top leader of the HLIs. This is in congruent with Ghasia et al. 2020 and Mtebe (2015) who have it that developing countries have started deploying e-learning technology before developing expertise for its management.

\section{Conclusions and Recommendations \\ Conclusions}

There is limited use of e-learning technology among HLIs in Tanzania. The e-learning implementation is in terms of tuition fee payment, results section, online learning and presentation of research proposals through mobile technologies and Zoom. Furthermore, the e-learning implementation is guided by the translation process that the government through the Ministry of Education (main actor) proposed, the online and or ICT enabled teaching and learning. The blended learning remains the main stepping stone towards complete e-learning implementation in HLIs. However, HLIs are challenged with cost of network connectivity, weak ICT infrastructure and inadequate skills for elearning among students and lecturers.

\section{Recommendations}

It is important for the government to make more emphasis on development of e-learning policies which will increase participation, commitment and accountability in HLIs. It is also important for HLIs to redefine e-learning strategies and develop facilities that will enhance transformations in teaching and learning amidst the Covid 19 Pandemic. This requires good internet networks as well as availability of robust learning management systems. Furthermore, HLIs should establish collaboration with other learning institutions within and outside the country for sustainable e-learning outcomes.

\section{References}

Aboagye, E., Yawson, J. A., \&Appiah, K. N. (2020). COVID-19 and E-learning: The Challenges of Students in Tertiary Institutions. Social Education Research, 2(1), pp. 1-8. https://doi.org/10.37256/ser. 212021422.

Afarikumah, E., \& Kwankam, S. Y. (2013). Deploying actor-network theory to analyse telemedicine implementation

in

Ghana. Science, 1(2), pp. 77-84.

Baines, P. R. (2017). Technological impacts on market attitudes and behaviors. Psychology and Marketing, 34(4), pp. 351-355.

Bijker, W.E., Hughes, T.P., Pinch, T., \&Douglas, D.G. (2012). The Social Construction of Technological Systems: New Directions in the Sociology and History of Technology. MIT Press, Boston.

Callon, M. (1986). The sociology of Actor-Network: The case of Electric Vehicle. Mapping the Dynamics of Science and Technology. In Callon, M., Law, J., and Rip, A. London, Macmillan Press: pp. 19-34.

Elbardan H., \&Kholeif A.O. (2017). An Interpretive Approach for Data Collection and Analysis.In: Enterprise Resource Planning, Corporate Governance and Internal Auditing. Palgrave Macmillan, Cham. https://doi.org/10.1007/9 78-3-319-549903_5.

Ghasia, M., Machumu, H., Zhu, C \&DePryck, K. (2020). Reflection on e-learning system of the Mzumbe University in Tanzania: Successes, challenges and way forward. International Journal of Education and Development using Information and Communication Technology (IJEDICT), 16(2), pp. 109-121.

Innocent, W. A., \&Masue, O. S. (2020). Applicability of E-learning in Higher Learning Institutions in Tanzania. International Journal of Education and Development using Information and Communication Technology (IJEDICT), 2020, 16(2), pp. 242249.

Islam, A. N., Mäntymäki, M., \&Turunen, M. (2019). Why do blockchains split? An actor-network perspective on Bitcoin splits. Technological Forecasting and Social Change, 148, https://doi.org/10.1016/j.techfore.2019.119 743.

Kwofie, B., Tetteh, E. D., \&Coffie, C. P. K. (2020). Institutional E-Learning Implementation: An Actor-Network Theory (ANT) Perspective. In Contemporary Applications of Actor 
Network Theory (pp. 99-119). Palgrave Macmillan, Singapore.

Kwofie, B. (2015). E-learning Implementation in Higher Education Institutions (Doctoral dissertation, Department of Electronic Systems, Aalborg University).

Latour, B. (2005). Reassembling the social: an introduction to Actor-Network Theory. Oxford: Oxford University Press.

Law, J. (1986). On power and its tactics; a view from the sociology of science. Sociological Review 34, pp. 1-38.

Law, J. (1992). Notes on the theory of the actornetwork: Ordering, strategy, and heterogeneity. Systems practice, 5(4), pp. 379-393.

Lizcano, D., Lara, J. A., White, B., et al. (2020). Blockchain-based approach to create a model of trust in open and ubiquitous higher education. Journal of Computing in Higher Education, 32, 109134. https://doi.o rg/1 0.1007/s1 2528-01909209-y.

Lwoga, E. (2012). Making learning and Web 2.0 technologies work for higher learning institutions in Africa. Campus-Wide Information Systems, 29(20), pp. 90-107. DOI 10.1108/10650741211212359.

Maatuk, A.M., Elberkawi, E.K., Aljawarneh, S., Rashaideh, H., \&Alharbi, H. (2021). The COVID-19 pandemic and E-learning: challenges and opportunities from the perspective of students and instructors. Journal of Computing in Higher

Education.https://doi.org/10.1007/s12528-02109274-2.

Mahyoob, M. (2020).Challenges of e-Learning during the COVID-19 Pandemic Experienced by EFL Learners. Arab World English Journal, 11 (4) 351-362. DOI: https://dx.doi.org/10.2409 3/awej/v ol11no4.23.

Markus, M. L., \& Rowe, F. (2018). Is IT changing the world? Conceptions of causality for information systems theorizing. MIS Quarterly, 42(4), pp. 1255-1280.

Ministry of Education, (2016). Information, Communication, Technology and E-Learning.
Retrieved from https://www.moe.go.tz /en/article/ Information, Communication, Technology and E-Learning.

Mtebe, J. S. \&Raphael, C. (2018). A Critical Review of eLearning Research Trends in Tanzania.Journal of Learning for Development - JL4D, 5(2), pp. 163-178.

Mtebe, J. S. (2015). Learning Management System success: Increasing Learning Management System usage in higher education in subSaharan Africa, International Journal of Education and Development using Information and Communication Technology, 11(2), pp. 51-64. Available at: http://ijedict.dec.uwi.edu/viewarticle.php?i $d=2005$.

Mtebe, J. S., Fulgence, K., \& Gallagher, M. S. (2021). COVID-19 and Technology Enhanced Teaching in Higher Education in SubSaharan Africa: A Case of the University of Dar es Salaam, Tanzania. Journal of Learning for Development, 8(2), pp. 383-397.

Mtega, W. P. (2021). Using WhatsApp Messenger for improving learners' engagement in teaching and learning: a case of undergraduate students at the Sokoine University of Agriculture, Tanzania. Library

Philosophy and Practice (e-journal). 4809. https://digitalcommons.unl.edu/libphilprac/ 4809.

Mwakyusa, W. P., \&Mwalyagile, N. V. (2016). Impediments of E-Learning Adoption in Higher Learning Institutions of Tanzania: An Empirical Review. Journal of Education and Practice, 7(30), 152-160.

Nhatuve, D. (2021). Effectiveness of Online Learning during the Covid-19 Pandemic: A Case of One University in Zimbabwe. East African Journal of Education and Social Sciences (EAJESS), 2(3), pp.56-61.

Putnam, L. L., \&Banghart, S. (2017). Interpretive Approaches. The International Encyclopedia of Organizational Communication, pp. 117. doi:10.1002/9781118955567.wbieoc118

Ramadan, K., Elatresh, K., Alzain, A., \&Tokeser, U. (2019). An Analysis of Factors affecting Learners' attitudes towards the Integration 
of E-learning into the Higher Education System in Libya: Case Study; Misurata University. Australian Journal of Basic and Applied Sciences, 13(10), pp. 55-64. DOI: 10.22587/ajbas.2019.13.10.8

Sarker, S., \&Sidorova, A. (2006). Understanding business process change failure: An actor-network perspective. Journal of Management Information Systems, 23(1), pp. 51-86.

Shim, Y., \& Shin, D. (2019). Smartness in techno-nationalism? Combining actor-network theory and institutionalization to assess Chinese smart TV development. Technological Forecasting and Social Change, 139, pp. 87-98.

Shin, D. H. (2010). The effects of trust, security and privacy in social networking: A securitybased approach to understand the pattern of adoption. Interacting with computers, 22(5), pp. 428-438.
Twaakyondo, H. M., \& Munaku, M. (2012). A Steady Progress towards E-Learning in Tanzania; The Case of CVL-UDSM. ST-Africa 2012 Conference Proceedings Paul Cunningham and Miriam Cunningham (Eds) IIMC International Information Management Corporation,www.IST-Africa.org/Confer ence2012 Page 1 of 7.

Walsham, G. (1995). Interpretive case studies in IS research: nature and method. European Journal of Information Systems, (4), pp.7481.

Walsham, G. (1997). Actor-network theory and IS research: current status and future prospects. In A. S. Lee et al. (eds.), Proceedings of IFIP TC8 WG 8.2 international conference on Information systems and qualitative research (pp. 466480). London: Chapman and Hall. 